\title{
CAUSALITY RELATIONSHIP BETWEEN FOREIGN DIRECT INVESTMENT AND TOURISM
}

\author{
EIma SATROVIC ${ }^{1}$ Adnan MUSLIJA ${ }^{2}$
}

\begin{abstract}
This paper applies panel data regression model to investigate the relationship between foreign direct investment (FDI) and tourism in 113 countries during the period 1995-2015. Besides this, the paper attempts to research the potential causal relationship and cointegration between tourism industry and FDI while controlling for indicators such as consumption, trade openness and human capital. The obtained results indicate a significant positive impact of tourism on FDI. Moreover, three control variables are reported to be a significant determinant of foreign direct investments. The unidirectional causal relationship running from tourism to FDI is reported, implying that tourism allows these countries to expand their FDI. Consumption, trade openness and human capital are also reported to have a unidirectional causal relationship with FDI. Westerlund ECM panel cointegration test indicates mixed results on the cointegration between variables. Taking into account the obtained results, government can consider this relationship as an important tool for policy implication to achieve sustainable growth of the economy as well.
\end{abstract}

Keywords: Tourism, Foreign direct investment, Cointegration, Causality, Relationship JEL Classification: L83, D25, B23

\section{DOĞRUDAN YABANCI YATIRIM VE TURIZM ARASINDAKI NEDENSELLiK iLişKiSi}

Öz

Bu çalışma, 1995-2015 döneminde 113 ülkede, doğrudan yabancı yatırım (DYY) ve turizm arasındaki ilişkiyi incelemek için panel veri regresyon modeli uygulanmıştır. Bunun yanı sıra, kâğıt tüketim, ticarete açıklık ve insan sermayesi gibi göstergeleri denetlerken potansiyel nedensel ilişki ve turizm endüstrisi ile DYY arasındaki eşşizliği araştırmaya çalışmaktadır. Elde edilen sonuçlar, turizmin doğrudan yabancı yatırımlar üzerindeki önemli(olumlu) etkisini göstermektedir. Ayrıca, üç kontrol değişkeninin doğrudan yabancı yatırımların önemli bir belirleyicisi olduğu bildirilmektedir. Turizmden DYY'ye uzanan tek yönlü nedensel ilişki rapor edilmekte, bu da turizmin bu ülkelerin DYY'lerinin gelişmesine olanak sağladığını göstermektedir. Tüketim, ticaret açıklığı ve beşeri sermayenin de DYY ile tek yönlü bir nedensel ilişkiye sahip olduğu bildirilmektedir. Westerlund ECM paneli eş-bütünleşme testi, değişkenler arasında eş-bütünleşme üzerindeki karışık sonuçları gösterir. Elde edilen sonuçları göz önünde bulundurarak, hükümet bu ilişkiyi, ekonominin sürdürülebilir büyümesini sağlamak ve politika imaları için önemli bir araç olarak değerlendirebilmektedir.

Anahtar Kelimeler: Turizm, Doğrudan yabancı yatırım, Eşbütünleşme, Nedensellik, İlişki

JEL Kodları: L83, D25, B23

${ }^{1}$ Asst. Prof.; Çağ University, Turkey, Department of International Management, elmasatrovic@cag.edu.tr, ORCID: 00000002-8000-5543

${ }^{2}$ PhD candidate; University of Sarajevo, Bosnia and Herzegovina, adnanmuslija@msn.com, ORCID:0000-0002-8176-6600 


\section{Introduction}

Tourism industry nowadays is considered to be an important economic sector in both, developed and developing countries. Samimi et al. (2013: 59) highlight the importance of tourism industry in increasing the foreign exchange income. Moreover, the authors point out the great role of tourism in creating employment opportunities and contributing to the economic growth. Higher quality services and better hospitality tend to attract more tourists, increase earnings from tourism industry and to contribute to the economy as a whole (Satrovic and Muslija, 2017: 93).

UNWTO (2016: 5) emphasizes that tourism has become a leading economic sector. In addition to the economic strength of tourism industry, it also has a great potential to deal with some major world's challenges such as environmental issues and socioeconomic growth. This is why this research analyzes if there is any impact of FDI on tourism industry. Besides that, it is indicated by UNWTO (http://www2.unwto.org/tourism-stories) that tourism represents a livelihood source for one in eleven people at the global level. In addition, tourism is expected to have a great role in building the peace worldwide (UNWTO, 2016: 7).

The last observed year in this paper is 2015 (due to the data availability). The panel data on annual basis are used since these are more informative; enable to control for and explore individual heterogeneity and enable to explore the potential dynamics (Baltagi, 2005: 5). This is why data from the year 2015 are presented below to confirm the importance of tourism sector as a possible determinant of foreign direct investment. The rise of $4.4 \%$ in the arrivals of international tourists is reported in 2015. This year reports the growth that is above average. After the world financial crisis till nowadays, the rise of $4 \%$ or more in international arrivals is recorded. Therefore, the increase of 50 million overnight visitors worldwide is recorded in 2015 compared to 2014 (http://media.unwto.org/press-release/2016-01-18/international-tourist-arrivals-4-reach-record12-billion-2015). This growth is particularly evident in European, Asian and North American countries reaching the $5 \%$ annual growth. Taking into account aforementioned facts, many governments aim to do necessary changes to develop tourism industry. This is the case especially in developing countries since tourism is expected to contribute foreign direct investments as well as economic growth of these countries.

Rajapakse (2016: 183) defines FDI as an investment in terms of assets that inflows to host from foreign country. It is crucial for countries to understand what drives companies to invest aboard, given that FDI contributes to their economic growth and development (Yazdi et al., 2017: 2). Foreign capital is used to support land business or building projects of new equipment. Therefore, FDI are in general connected to long-term project running from foreign to host country since both, land business or new equipment can hardly be removed. Yet, tourism sector is financed in great percentage using FDI (Rajapakse, 2016: 183). In addition, Yazdi et al. (2017: 2) point out the essential role of foreign direct investment in global economy since it has a great potential to contribute to tourism industry and domestic economy as a whole. However, there is surprisingly little empirical research on the impact of FDI on tourism development. Many studies on FDI exist, but only a few analyze the tourism sector and its implications (Yazdi et al., 2017: 2).

Therefore, FDI is expected to help developing countries to converge to developed by promoting tourism development and increasing employment. This is due to the fact that FDI helps to satisfy the increased demand for goods and services in tourism industry by providing necessary infrastructure. In addition, the increased demand in terms of transport, cuisine and hotels due to the tourism industry attracts foreign investors.

Taking into account the previous paragraph, the research question of this paper states: whether or not tourism development causes the further attracting of FDI or alternatively FDI strongly contributes to tourism development. Samimi et al. (2013: 60) indicate that a rigorous research on the matter has not been conducted quite extensively especially in terms of long-run and causal relationship. In addition, these papers do not take into account the latest available data. 
Therefore, the aim of this paper is to explore the link, if any, between tourism and FDI using panel data regression models. Furthermore, existence of causality and cointegrated relationships between variables of interest is tested using the panel of 113 countries. As an initial step, we have employed Westerlund ECM panel cointegration approach to explore the long-run relationship between FDI and tourism industry. Moreover, Dumitrescu and Hurlin (DH) Granger non-causality test is applied.

Hence, the importance of this study and its contribution to the literature to date can be summarized in the following: the present relationship will be overlooked from the two points of view: using linear static and dynamic panel data regression models initially and by exploring the potential causality relationship between economic terms of interest to give a more informative answer to the research question. In addition, last available data are used, as opposed to up-to-date studies, (year 2015 is included) and higher sample of countries is taken into account. Since, there were turbulent changes in both, tourism industry and FDI after the recent financial crisis, it is essential to take into account the last available data while analyzing the present relationship.

The importance of this study lies also in the fact that it suggests the unidirectional causal relationship running from tourism to FDI implying that tourism industry has a great potential to deal with some of the major challenges in the world such as the socioeconomic growth as well as environmental issues. Moreover, tourism industry is found to play a great role in both, developed and developing countries, since it contributes to the foreign direct investments that are found to be essential for the economic growth of these countries. Hence, the policy implications of this paper suggest that governments should do necessary changes to promote tourism industry in order to attract FDI and to achieve the sustainable growth of the economy as a whole. One of the ways to achieve that is to increase the quality of the services; to improve the hospitality; to educate more tourism managers and to educate the citizens of the host countries on the importance of tourism industry and on their great role in increasing the emotional attachments of the tourists to some place.

This paper proceeds as follows. In Section 2 a review of empirical and theoretical literature on the relationship between variables of interest is given. Furthermore, we give the description of data, variables and methodology in Section 3. Section 4 reports empirical results and give necessary interpretations. Section 5 provides a concluding remark.

\section{Literature Review}

Samimi et al. (2013: 64) explore whether or not the Granger causal relationship exists between tourism related FDI. The research was conducted for developing countries. In order to avoid spurious correlation, the authors have conducted empirical investigation in three steps. First, they have tested for the stationarity of variables using Im, Pesaran and Shin test. Moreover, they explore the potential relationship between variables of interest in the long-run using the panel cointegration test. In their third step, they test whether or not Granger causality exists in the longrun. This empirical approach is supported by and Samimi et al. (2011: 28). The observed period is between 1995 and 2008. The obtained results suggest a cointegrating relationship in the long-run. The authors also report a bidirectional causal relationship between economic terms of interest in the long-run. However, there is no empirical evidence on the short-run relationship.

Andergassen and Candela (2013: 16) analyze the relationship between FDI and tourism in less developed countries. They aim to study the effects of a multinational's tourism investment on local economic development. The econometric technique in this paper includes calculating the optimal supply of tourism products. This empirical approach is also supported by Endo (2006: 600). The authors indicate that unique goods and services provided by touristic destination, if supplied by the local community, represent forward linkages of FDI in tourism.

A causal link from FDI to tourist arrivals arises since tourism industry requires a great amount of funding and FDI is recognized to be an important funding source. Therefore, business tourists 
link FDI and tourism industry in indirect way. These business tourists include foreign CEOs and entrepreneurs visiting many destinations worldwide and looking for investment opportunities. Selvanathan and Viswanathan (2009: 3) indicate that these tourists play an important role in increasing FDI in tourism industry in order to increase the quality and quantity of tourism-related services. Hence, the authors explore whether or not the FDI causes tourism and vice versa using the case of India. In terms of econometrics techniques, they have used Granger causality test for this purpose as opposed to Contractor and Kundo (1995) who were applying only the basic regression models. Moreover, graphical approach is used to detect a potential seasonal pattern. In addition, they have tested for the unit root of deseasonalized time-series using ADF test. They have also tested for the presence of structural change and for the cointegration. Lastly, they have tested for the Granger causality. Foreign direct investment is found to have a unidirectional causal relationship with tourism in India. These results tend to explain the exponential growth in both, FDI and tourism sector in India over the period of interest.

Chen (2010) study aims to give empirical evidence on the impact of FDI on tourism industry in China taking into account the fact the reforms in China after 1970s. The author uses following econometrics techniques: the case study method as well as the comparative method. The results suggest that the impact of FDI on tourism sector differs among coastal and other regions in terms of hotel sector, travel agencies as well as tourism-related features.

Tourism is reported to be an important exporting sector worldwide especially in terms of developing countries (Rajapakse, 2016: 183). It contributes foreign exchange income and creates employment opportunities. Therefore, tourism is playing an important role in stimulating overall economic growth. In addition, tourism sector is recognized as a promoter of economic growth and development in developing countries. This author explores whether or not FDI in tourism has a causal relationship with arrivals of foreign tourist in Sri Lanka. The econometric techniques include: VAR, Granger causality, non-stationarity test as well as cointegration test. This empirical approach is supported by Gunduz and Hatemi-J (2005: 499), Zortuk (2009: 231) and Yıldırım and Öcal (2004: 131). The observed period ranges from first quarter of 2005 to the last quarter of 2013. The analyses suggest no cointegration between FDI in tourism and the arrivals of foreign tourists in the case of Sri Lanka.

Yazdi et al. (2017: 1) aim to explore the impact of foreign direct investment (FDI), official exchange rate and trade on international tourism using panel data of 27 countries over 1995-2014. The econometric technique includes PMG estimator suggesting no causal relationship between tourism activity and FDI. In addition, a real exchange rate and trade openness are reported to have a bidirectional causal relationship with tourism activity supporting the literature on the supporting role of FDI in tourism industry in the case of EU countries.

The influence of tourism on foreign direct investment is investigated by Sanford and Dong (2000: 205). The empirical analysis is based on the TOBIT model while the results report a significant and positive impact of tourism on FDI using the case of USA. In addition, the authors suggest that tourism is strongly associated with capital-intensive investments providing no evidence on the industry-specific effects.

Dwyer and Forsyth (1994: 512) indicate that tourism industry strongly relies on the foreign direct investments worldwide but the impact has been overlooked. Therefore, their research aims to give a summary of FDI in tourism using the case of Australia. At the end the authors provide an overview of the costs and benefits connected with foreign direct investments in tourism industry.

Overall, the authors have used different econometric techniques based on both, time-series and panel data, to analyze the relationship between economic terms of interest. The findings of these papers suggest the mixed results on the relationship between tourism and foreign direct investments. Therefore the question whether tourism development causes the further attracting 
of FDI or alternatively FDI strongly contributes to tourism development remains open. This research attempts to give an answer to this question.

\section{Data and Methodology}

\subsection{Data}

In order to investigate the relationships between international tourism receipts in current US\$ (TOUR), foreign direct investment, net inflows in current US\$ (FDI), household final consumption expenditure per capita in constant 2010 US\$ (CON) as a proxy of living standards, gross enrolment ratio, secondary (\% of total population) as a proxy of human capital (HumCap) and exports of goods and services (\% of GDP) as a proxy of trade openness (EXPgdp), panel data models are used. The most popular measures of standard of living are: consumption and income ( $O$ 'Donnell et al., 2008: 69). The authors also emphasize that both of the variables should be taken with cautiousness. This is since there are, in general, substantial differences between measured income and consumption. These differences are conceptual, i.e. it is possible to save some income and to borrow money in order to finance consumption. Hence, the debate about which is better proxy of living standards is still open. In general, O'Donnell et al. (2008: 70) suggest using consumption in the case of developing countries. Since, most of the countries in this research are developing, consumption is considered to be appropriate proxy of standard of living. The panel model dataset consists of 113 countries (Appendix 1). The data source is the World Data Bank (WDI, 2017) for the period 19952015. The description of the variables is given in Appendix 2.

\subsection{Methodology}

The macroeconomic foundation used in the regression aims to estimate the FDI while including tourism. Since, Walsh and Yu (2010: 9) indicate that control variables do not slightly change the results obtained in the original model, this paper controls for the impact of human capital, consumption expenditure and trade openness. Yazdi et al. (2017: 8) control for the impact of trade openness while Walsh and Yu (2010: 18) suggest the inclusion of living standards as a determinant of FDI. Borensztein, et al. (1995: 13-14) suggest the necessity to control for human capital since FDI is reported to have the strongest relationship with growth in countries that have more developed human capital. The econometric specification of the model can be written as follows:

$\mathrm{FDI}_{\mathrm{it}}=\beta_{0}+\beta_{1}$ TOUR $_{\mathrm{it}}+\beta_{2} \mathrm{CON}_{\mathrm{it}}+\beta_{3}$ HumCap $_{\mathrm{it}}+\beta_{4} \mathrm{EXPgdp}_{\mathrm{it}}+\varepsilon_{\mathrm{it}}$

where $i$ stands for the individual (countries in this case), and $t$ stands for the time period. The meaning of variables is described above. $\beta_{0}$ is constant term, $\beta_{1}-\beta_{4}$ are regression parameters while $\varepsilon_{i t}$ represents error term. Hausman test is used to decide between fixed and random effect. Taking into account the potential dynamic phenomenon; endogeneity, heteroscedasticity and serial correlation issue, GMM method is employed.

\subsubsection{Generalized Method of Moments}

Greene (2003: 308) suggests the estimation problems in the random effect model due to the fact that the lagged dependent variable (LDV) is found to be correlated with the compound disturbance in the model. Hence, there is a need to propose another estimator different from FGLS and LSDV. For this purpose, Green (2003: 308) suggests the approach based on GMM estimator that is accepted in this paper as well. The author suggests taking first differences from the model in order to sweep the heterogeneity in fixed or random effects models. However, there is still complication arising from the correlation between the disturbance and the LDV. By eliminating group effect and assuming that the time-series is long enough, the simple estimator based on instrumental variables can be employed. Hence, "in the context of GMM estimator, Hausman and Taylor (HT) formulation of the random effects model is extended to include the lagged dependent variable" (Greene, 2003: 308). Moreover, the author shows "that efficiency gains are available by using a larger set of moment conditions" that are used to produce the instrumental variable estimator (Greene, 2003: 308-309). 
To incorporate dynamics into the model, equation (1) can be rewritten as an AR (1) model, that is (Eq. 2):

$y_{i t}=\alpha_{t}+(v+1) y_{i t-1}+\beta x_{i t}+u_{i}+\varepsilon_{i t}$

where $y_{i t}$ is the FDI, $y_{i t-1}$ is the lagged value of the FDI, $x_{i t}$ represents a vector of explanatory variables, $u_{i}$ is individual effect, $\varepsilon_{i t}$ - error term while $\alpha_{t}$ represents the period-specific intercept terms to capture changes common to all countries.

In addition to panel regression model, Granger causality test was applied to comprehend the direction of the relationship among FDI, tourism and control variables. A set of criteria, known as diagnostic test were applied before Granger test. Cointegration is also analyzed.

\subsubsection{Unit root test}

If data have unit roots, it is important to convert this data into stationary as non-stationary data may lead to misleading results. Augmented Dickey-Fuller (ADF) test is one of the most popular techniques to check whether data has unit root or not. Fisher-type tests that specify Augmented Dickey-Fuller are used in this paper. The hypothesis to be examined with unit root test is:

$\mathrm{H}_{0}$ : All panels contain unit roots

$\mathrm{H}_{1}$ : At least one panel is stationary.

\subsubsection{Cointegration test}

Cointegration method as a statistical tool aims to investigate cointegration among variables. This method was developed in order to determine the linear combination of two or more nonstationary series that might be stationary. Cointegration implies existence of causality between variables but direction of the causal relationship is not indicated by this method. Westerlund errorcorrection-based panel cointegration tests are used for this purpose. The null hypothesis of this test assumes no cointegration. In order to give evidence on the rejection of null hypothesis it is tested whether or not "the error correction term in an conditional ECM is equal to zero" (Westerlund, 2005: 19). The null hypothesis of no cointegration is rejected in the case when the null of no error correction is rejected (Westerlund, 2005: 19).

\subsubsection{Granger causality test}

Dumitrescu and Hurlin (DH) Granger non-causality test is applied to forecast one time series from another one. The assumption of the Granger causality is that an independent variable Granger causes dependent if the dependent variable can be better anticipated using the historical values of both variables rather than of single dependent variable. If there is cointegration in the long-run between any two variables, bidirectional or unidirectional Granger causality between variables is expected. Lopez and Weber (2017: 3) formalize the regression model to test for the causality:

$\mathrm{y}_{\mathrm{i} . \mathrm{t}}=\alpha_{\mathrm{i}}+\sum_{\mathrm{k}=1}^{\mathrm{K}} \beta_{\mathrm{ik}} \mathrm{y}_{\mathrm{i}, \mathrm{t}-\mathrm{k}}+\sum_{\mathrm{k}=1}^{\mathrm{k}} \mu_{\mathrm{ik}} \mathrm{x}_{\mathrm{i}, \mathrm{t}-\mathrm{k}}+\varepsilon_{\mathrm{i} . \mathrm{t}}$

where $x_{i . t}$ and $y_{i . t}$ are the observations of two stationary variables for individual $i$ in period $t$. It is tested whether or not the present values of dependent variable are influenced by the past values of independent variables. The null hypothesis assumes the absence of causality for all individuals of interest.

\section{Empirical Results and Interpretations}

This section starts by presenting descriptive statistics. Table 1 summarizes the obtained results: 
Table 1: Descriptive Statistics

\begin{tabular}{cccccc}
\hline stats & FDI & TOUR & CON & HumCap & EXPgdp \\
\hline mean & 12200000000 & 7330000000 & 8928.77 & 85.53 & 43.66 \\
sd & 38800000000 & 17500000000 & 9081.41 & 23.72 & 30.62 \\
skewness & 7.30 & 6.74 & 1.30 & -0.56 & 2.72 \\
kurtosis & 81.62 & 66.98 & 3.95 & 4.17 & 13.41 \\
\hline
\end{tabular}

Source: Authors

All of the variables are reported to deviate from normal distribution (skewness-kurtosis test). Moreover, mean and standard deviation values of FDI and TOUR variables are dramatically higher than same values of CON variable since CON variable is expressed per capita. Due to these issues and in order to ease the interpretation, variables are expressed in natural logarithmic forms. Furthermore, all of the models are estimated using fixed and random effects. Based on the Hausman test, one of the models is selected and these results are presented below. Fixed effects models suggest that null hypothesis on no serial correlation and homoscedasticity are rejected indicating that these results may not be valid. Hence, GMM method is used to control for the potential endogeneity issue, serial correlation, heteroscedasticity as well as the dynamics of the variables of interest. The obtained results are reported below. Taking into account the estimation issues assigned with $\mathrm{FE}$, only the results of GMM are interpreted.

Table 2: Panel Data Estimation, Dependent Variable FDI

\begin{tabular}{lcc}
\hline VARIABLES & $(1)$ & $(2)$ \\
InFDI = L1. & $\mathrm{FE}$ & $0.462^{* * *}$ \\
& & $(0.00297)$ \\
InTOUR & $0.717^{* * *}$ & $0.280^{* * *}$ \\
& $(0.0298)$ & $(0.00304)$ \\
InCON & $0.340^{* * *}$ & $0.239^{* * *}$ \\
& $(0.0610)$ & $(0.0174)$ \\
InHumCap & $0.381^{* * *}$ & $0.113^{* * *}$ \\
& $(0.0990)$ & $(0.0183)$ \\
InEXPgdp & $0.356^{* * *}$ & $0.807^{* * *}$ \\
& $(0.0813)$ & $(0.0163)$ \\
Constant & 0.102 & 0.155 \\
& $(0.755)$ & $(0.125)$ \\
Observations & & 1,944 \\
Number of id & 2,274 & 113 \\
Wooldridge test for autocorrelation $(p)$ & 0.000 & \\
Wald test for heteroskedasticity $(p)$ & 0.000 & 0.110 \\
A-Bond test $(p)$ & & 1.000 \\
Sargan test $(p)$ & &
\end{tabular}

Note: Standard errors in parentheses, $* * * p<0.01, * * p<0.05, * p<0.1$

Source: Authors

The assumption on overall validity of instruments and second order autocorrelation are not rejected using the Sargan and serial-correlation tests which support the obtained empirical results. Coefficient between FDI and tourism is positive and significant (0.280). The obtained results also indicate a significant positive relationship between all of the control variables and FDI. Trade openness is reported to have a strongest significant positive impact on FDI. 
In addition to panel regression model, Granger causality test was applied to comprehend the direction of relationship among FDI, tourism and control variables. Diagnostic test was applied before Granger test.

Table 3: Fisher-Type Unit Root Test

\begin{tabular}{|c|c|c|c|c|c|c|c|c|c|}
\hline \multicolumn{2}{|c|}{ InFDI } & \multicolumn{2}{|c|}{ InTOUR } & \multicolumn{2}{|c|}{ InCON } & \multicolumn{2}{|c|}{ InHumCap } & \multicolumn{2}{|c|}{ InEXPgdp } \\
\hline $\begin{array}{l}\text { Statisti } \\
\text { c }\end{array}$ & $p$-value & Statistic & $p$-value & $\begin{array}{l}\text { Statisti } \\
\mathrm{c}\end{array}$ & $p$-value & Statistic & $\begin{array}{c}\mathrm{p}- \\
\text { value }\end{array}$ & Statistic & $\begin{array}{c}\mathrm{p}- \\
\text { value }\end{array}$ \\
\hline 424.68 & 0.000 & 236.799 & 0.29 & $\begin{array}{l}222.42 \\
8\end{array}$ & 0.555 & 529.63 & 0.000 & 371.04 & 0.000 \\
\hline-3.071 & 0.001 & 1.873 & 0.97 & 0.9504 & 0.829 & -8.416 & 0.000 & -2.072 & 0.019 \\
\hline-4.896 & 0.000 & 1.483 & 0.93 & 0.8442 & 0.801 & -10.26 & 0.000 & -3.241 & 0.001 \\
\hline 9.345 & 0.000 & 0.508 & 0.30 & -0.1680 & 0.567 & 14.281 & 0.000 & 6.822 & 0.000 \\
\hline
\end{tabular}

Source: Authors

The presence of unit root is initially tested for the variables expressed in natural logarithmic forms. Fisher-type tests that specify Augmented Dickey-Fuller are used in this paper. Table 3 summarizes the results of unit root test. These findings indicate that InTOUR and InCON contain unit root (for a $5 \%$ level of significance). For this reason, the first difference of these variables are calculated and used in research to follow. The first difference is reported to be stationary in terms of variables of interest.

Table 4: Cointegration Test

\begin{tabular}{ccccc}
\hline & Statistic & Value & Z-value & P-value \\
\hline InFDI- & Gt & -1.8460 & -0.8100 & 0.2090 \\
D.InTOUR & Ga & -10.9780 & -7.4900 & 0.0000 \\
& Pt & -17.5700 & -2.1950 & 0.0140 \\
& Pa & -3.7310 & 1.1950 & 0.8840 \\
\hline InFDI- & Gt & -1.4670 & 3.6720 & 1.0000 \\
InEXPgdp & Ga & -6.3360 & 1.5750 & 0.9420 \\
& $\mathrm{Pt}$ & -18.4940 & -3.1240 & 0.0010 \\
& $\mathrm{~Pa}$ & -6.0160 & -4.2760 & 0.0000 \\
\hline InFDI- & $\mathrm{Gt}$ & -1.5560 & 2.6240 & 0.9960 \\
D.InCON & $\mathrm{Ga}$ & -6.8680 & 0.5360 & 0.7040 \\
& $\mathrm{Pt}$ & -24.4850 & -9.1500 & 0.0000 \\
& $\mathrm{~Pa}$ & -7.0280 & -6.6980 & 0.0000 \\
\hline InFDI- & $\mathrm{Gt}$ & -1.6260 & 1.7900 & 0.9630 \\
& $\mathrm{Ga}$ & -7.1410 & 0.0030 & 0.5010 \\
& $\mathrm{Pt}$ & -25.3300 & -10.0000 & 0.0000 \\
& $\mathrm{~Pa}$ & -7.1630 & -7.0220 & 0.0000 \\
\hline
\end{tabular}

Source: Authors

Next, to test the cointegration between variables Westerlund ECM panel cointegration test has been applied and results are concluded (in Table 4). Cointegration test indicates mixed results on the cointegration between the variables. Some of the statistics provide strong evidence on cointegration while some of the results indicate no evidence on cointegration between the variables. However, at least one statistics for all four combinations suggests the relationship existing in the long-run. But this test does not indicate the direction of this relationship. Therefore, 
in order to explore the Granger causality between variables, DH Granger non-causality test is applied as the final step. Serial correlation and heteroscedasticity are not assumed to cause serial estimation issues due to the reasons explained in Stojkoski et al. (2017: 11-13).

Table 5: DH Granger Non-Causality Test Results

\begin{tabular}{|c|c|c|c|c|c|}
\hline $\begin{array}{l}\text { Dependent } \\
\text { variable }\end{array}$ & $\begin{array}{l}\text { Independent } \\
\text { variable }\end{array}$ & W-bar & Z-bar & $\begin{array}{l}\text { Z-bar } \\
\text { tilde }\end{array}$ & Decision \\
\hline \multirow{4}{*}{ InFDI } & D.InTOUR & 2.848 & $\begin{array}{c}13.894 \\
(0.000)^{*}\end{array}$ & $\begin{array}{c}10.253 \\
(0.000)^{*}\end{array}$ & $\begin{array}{c}\text { Unidirectional } \\
\text { relation - tourism to FDI }\end{array}$ \\
\hline & D.InCON & 3.146 & $\begin{array}{c}16.128 \\
(0.000)^{*}\end{array}$ & $\begin{array}{c}12.029 \\
(0.000)^{*}\end{array}$ & $\begin{array}{l}\text { Unidirectional } \\
\text { relation - consumption } \\
\text { to FDI. }\end{array}$ \\
\hline & InHumCap & 2.059 & $\begin{array}{c}7.959 \\
(0.000)^{*}\end{array}$ & $\begin{array}{c}5.533 \\
(0.000)^{*}\end{array}$ & $\begin{array}{l}\text { Unidirectional } \\
\text { relation - human capital } \\
\text { to FDI. }\end{array}$ \\
\hline & InEXPgdp & 2.029 & $\begin{array}{c}7.734 \\
(0.000)^{*}\end{array}$ & $\begin{array}{c}5.354 \\
(0.000)^{*}\end{array}$ & $\begin{array}{l}\text { Unidirectional } \\
\text { relation - trade } \\
\text { openness to FDI }\end{array}$ \\
\hline
\end{tabular}

Note: ${ }^{*}$ - $p$ value

Source: Authors

The unidirectional causal relationship running from tourism to FDI is reported, implying that tourism allows these countries to expand their FDI. Consumption, trade openness and human capital are also reported to have a unidirectional causal relationship with FDI. The test does not provide evidence on the bidirectional relationship between FDI and other variables. Even though cointegration test indicates mixed results on the cointegration between variables, causality test gives clear evidence on the unidirectional relationship between the variables.

\section{Conclusion}

The motivation for this research has arose from the fact that taking into account results of the up-to-date studies, the question whether tourism development causes the further attracting of FDI or alternatively FDI strongly contributes to tourism development remains open. In addition, it is important to emphasize that the rigorous empirical research on the causal and long-run relationship between variables of interest is not conducted in research to date. This is why, this paper aims to fill in this gap in literature by exploring the relationship between tourism and FDI applying panel data regression models as well as by conducting causality and cointegration analysis. Westerlund ECM panel cointegration is used to test the relationship in the long-run while Dumitrescu and Hurlin (DH) Granger non-causality test explores the potential Granger causality. The existence of a long-run relationship between variables is tested using a Westerlund ECM panel cointegration approach while a panel Granger causality is examined applying Dumitrescu and Hurlin (DH) Granger non-causality test. Panel data are used for 113 countries over the period 19952015.

The link between FDI and tourism is estimated using fixed and random panel data models. Hausman test suggests FE models. Moreover, GMM method is employed. The assumption on overall validity of instruments and second order autocorrelation are not rejected using the Sargan and serial-correlation tests which support the obtained empirical results. Coefficient between FDI and tourism is positive and significant (0.280). This result is supported by Yazdi et al. (2017), Kaur and Sarin (2016), Samimi et al. (2013). The obtained results also indicate a significant positive impact of all of the control variables on FDI. Trade openness is reported to have a strongest significant positive impact on FDI. In order to conduct causality and cointegration analysis, there was a need to test for unit root. For this purpose, Fisher-type tests that specify Augmented DickeyFuller are used in this paper. These findings indicate that InTOUR and InCON contain unit root (for a $5 \%$ level of significance). For this reason, the first difference of these variables are calculated and 
used in research to follow. The first difference is reported to be stationary in terms of variables of interest.

To test the cointegration between stationary variables, Westerlund ECM panel cointegration test has been applied. Cointegration test indicates mixed results on the cointegration between variables. Some of the statistics provide strong evidence on cointegration while some of the results indicate no evidence on cointegration between the variables. However, at least one statistics for all four combinations suggests the relationship existing in the long-run. But this test does not report the direction. Therefore, in order to explore the Granger causality between variables, DH Granger non-causality test is applied as the final step.

The unidirectional causal relationship running from tourism to FDI is reported, implying that tourism allows these countries to expand their FDI. Consumption, trade openness and human capital are also reported to have a unidirectional causal relationship with FDI. Taking into account obtained results, government can consider this relationship as an important tool for policy implication to achieve sustainable growth of the economy as well. In terms of areas for further research we highlight the need to introduce the regional dummy variable as well as to explore whether or not there are differences between developed and developing countries. Moreover, future researches can focus on the role of the recent financial crisis in the relationship of interest. As last proposition, there is a necessity to explore whether or not the political stability plays moderating role between variables of interest.

Appendix 1: List of the countries

\begin{tabular}{|c|c|c|c|c|}
\hline Algeria & Cyprus & Japan & New Zealand & Thailand \\
\hline Argentina & Czech Rep. & Jordan & Nicaragua & Trinidad and Tobago \\
\hline Armenia & Denmark & Kazakhstan & Nigeria & Tunisia \\
\hline Australia & Dominican $\mathrm{R}$. & Kenya & Norway & Turkey \\
\hline Austria & Ecuador & Korea, Rep. & Oman & Uganda \\
\hline Bahamas & Egypt & Kuwait & Pakistan & Ukraine \\
\hline Bahrain & Estonia & Kyrgyz Rep. & Panama & Unit. Arab E. \\
\hline Bangladesh & Ethiopia & Lao PDR & Paraguay & United Kin. \\
\hline Barbados & Fiji & Latvia & Peru & USA \\
\hline Belarus & Finland & Lebanon & Philippines & Uruguay \\
\hline Belgium & France & Libya & Poland & Venezuela, RB \\
\hline Brazil & Germany & Lithuania & Portugal & Yemen, Rep. \\
\hline Bulgaria & Ghana & Luxembourg & Romania & Zimbabwe \\
\hline Cambodia & Greece & Macedonia & Russian Fed. & \\
\hline Cameroon & Honduras & Malaysia & Senegal & \\
\hline Canada & Hong Kong & Mali & Sierra Leone & \\
\hline Cen. Afric. R. & Hungary & Malta & Singapore & \\
\hline Chile & Iceland & Mauritius & Slovak Rep. & \\
\hline China & India & Mexico & Slovenia & \\
\hline Colombia & Indonesia & Moldova & Spain & \\
\hline Congo, Rep. & Iran & Mongolia & Sri Lanka & \\
\hline Costa Rica & Iraq & Morocco & Sudan & \\
\hline Cote d'Ivoire & Ireland & Namibia & Sweden & \\
\hline Croatia & Italy & Nepal & Switzerland & \\
\hline Cuba & Jamaica & Netherlands & Syria & \\
\hline
\end{tabular}


Appendix 2: Description of the variables

\begin{tabular}{|c|c|c|c|}
\hline Variable & Definition & $\begin{array}{c}\text { Unit of } \\
\text { measurement }\end{array}$ & Source \\
\hline TOUR & International tourism receipts in current US\$ & USD & World Data Bank \\
\hline FDI & $\begin{array}{l}\text { Foreign direct investment, net inflows in } \\
\text { current US\$ }\end{array}$ & USD & World Data Bank \\
\hline CON & $\begin{array}{l}\text { Household final consumption expenditure } \\
\text { per capita in constant } 2010 \text { US\$ }\end{array}$ & USD & World Data Bank \\
\hline HumCap & $\begin{array}{l}\text { Gross enrolment ratio, secondary (\% of total } \\
\text { population) }\end{array}$ & $\%$ & World Data Bank \\
\hline EXPgdp & Exports of goods and services (\% of GDP) & $\%$ & World Data Bank \\
\hline
\end{tabular}

\section{References}

Andergassen, R. and Candela, G. (2013). Less Developed Countries, Tourism Investments and Local Economic Development, Review of Development Economics, 17(1), 16-33.

Baltagi, B.H. (2005). Econometric Analysis of Panel Data. Southern Gate, Chichester: John Wiley \& Sons Ltd.

Borensztein, E., de Gregorio, J. and Lee, J.W. (1995). How Does Foreign Direct Investment Affect Economic Growth? NBER Working Paper No. 5057.

Chen, X. (2010). The Influence of FDI on China's Tourism Industry. Master thesis, source: http://aut.researchgateway.ac.nz/bitstream/handle/10292/904/ChenX.pdf?sequence=4 \&isAllowed=y

Contractor, F.J. and Kundu, S.K. (1995). Explaining Variation in the Degree of Internationalisation across Firms: the Case of the Hotel Industry, Journal of International Management, 1(1), 87-123.

Dwyer, L., and Forsyth, P. (1994). Foreign Tourism Investment: Motivation and Impact, Annals of Tourism Research, 21(3), 512-537.

Endo, K. (2006). Foreign Direct Investment in Tourism - Flows and Volumes, Tourism Management, 27, 600-614.

Greene, W.H. (2003). Econometric Analysis (5th ed.). New York: Pearson Education, Inc.

Gunduz, L., and Hatemi-J, A. (2005). Is the Tourism-Led Growth Hypothesis Valid for Turkey? Applied Economics Letters, 12(8), 499-504.

Kaur, H. and Sarin, V. (2016). Causality Relationship between GDP, FDI, Tourism: Empirical Evidence from India, I J A B ER, 14, 2605-2613.

Lopez, L. and Weber, S. (2017). Testing for Granger Causality in Panel Data, Online article, source: https://www.unine.ch/files/live/sites/irene/files/shared/documents/Publications/Worki ng\%20papers/2017/WP17-03_V2.pdf.

O’Donnell, O., van Doorslaer, E., Wagstaff, A. and Lindelow, M. (2008). Analyzing Health Equity Using Household Survey Data. Washington, D.C.: The World Bank.

Rajapakse, C.R. (2016). The Relationship between Foreign Direct Investment and Tourism Development: Evidence from Sri Lanka, International Journal of Research in Economics and Social Sciences, 6(5), 183-193.

Samimi, A.J., Sadeghi, S., Sadeghi, S. (2013).The Relationship between Foreign Direct Investment and Tourism Development: Evidence from Developing Countries, Institutions and Economies, 5(2), 59-68. 
Samimi, A.J., Sadeghi, S., and Sadeghi, S. (2011). Tourism and Economic Growth in Developing Countries: P-VAR Approach, Middle-East Journal of Scientific Research, 10(1), 28-32.

Sanford, D. M., and Dong, H. (2000). Investment in Familiar Territory: Tourism and New Foreign Direct Investment, Tourism Economics, 6(3), 205-219.

Satrovic, E. and Muslija, A. (2017). Foreign Direct Investments and Tourism: Empirical Evidence from Turkey, ICPESS Proceedings, 2, 88-100.

Selvanathan, E.A. and Viswanathan, B. (2009). Causality between Foreign Direct Investment and Tourism: Empirical Evidence from India, working paper, source: https://editorialexpress.com/cgi-

bin/conference/download.cgi?db_name=ACE09\&paper_id=230.

Stojkoski, V., Popova, K. and Tevdovski, D. (2017). Financial Development and Growth: Panel Cointegration Evidence from South-Eastern and Central Europe, MPRA Paper No. 80802, source: https://mpra.ub.unimuenchen.de/80802/1/MPRA_paper_80802.pdf

Walsh, J.P. and Yu, J. (2010). Determinants of Foreign Direct Investment: A Sectoral and Institutional Approach. IMF Working Paper, source: https://www.imf.org/external/pubs/ft/wp/2010/wp10187.pdf.

Yazdi, S.K., Nateghian, N. and Rezaie, N.S. (2017). The Causality Relationships between Tourism Development and Foreign Direct Investment: An Empirical Study in EU Countries, Journal of Policy Research in Tourism, Leisure and Events, 9, 1-18.

Yıldırım, J., and Öcal, N. (2004). Tourism and Economic Growth in Turkey, Ekonomik Yaklaşım, 15(52-53), 131-141.

Westerlund, J. (2005). Testing for Error Correction in Panel Data, Working Papers, source: http://portal.research.lu.se/portal/files/5605735/2061468.

Zortuk, M. (2009). Economic Impact of Tourism on Turkey's Economy: Evidence from Cointegration Tests, International Research Journal of Finance and Economics, 25, 231-239. 